\title{
The Relationship between Motivation Factors and Unsafe Action on Passenger Ship Crews in Tanjung Pinang
}

\author{
Jhonni Wahyudi ${ }^{1}$, Gerry Silaban ${ }^{2}$, Destanul Aulia ${ }^{2}$ \\ ${ }^{1}$ Master Student in Faculty of Public Health, Universitas Sumatera Utara, Medan, Indonesia \\ ${ }^{2}$ Lecturer in Faculty of Public Health, Universitas Sumatera Utara, Medan, Indonesia \\ Email: d.yent.cp@gmail.com
}

\begin{abstract}
:
This research deals with the relationship between motivation factors and unsafe action on passenger ship crews in Tanjung Pinang. This type of research is an analytical survey using cross sectional design aimed at explaining a situation by analyzing the relationship between individual factors and work factors with unsafe action on the crew of passenger ships in Tanjung Pinang City. The study was conducted at the port of Sri Bintan Pura in Tanjung Pinang City. The population in this study is the crew of passenger ships with the position of Captain, Mualim, KKM (Head of Engine Room), and Oiler in the port of Sri Bintan Pura Tanjungpinang City with the destination of Tanjungpinang to Batam. Based on the results of the study indicate that there is a significant relationship between motivation and unsafe action. In the multivariate test, it is known that motivation variable has an influence on unsafe action with $p$ value $=0.019$ and $\exp (B)$ value of 8.577 , which means that the motivation variable in the low category will cause unsafe action to be high by 8.577 times compared to the high motivation category. It can be conclude that the majority of respondents classified as young, have a high level of education, a new tenure, have a high income, good knowledge of occupational health and safety, high motivation, and unsafe action. Based on the bivariate analysis obtained levels of education, years of service, knowledge, motivation, related to unsafe action.
\end{abstract}

Keywords:

motivation factors; unsafe action; passenger ship crews

\section{Introduction}

Occupational Health and Safety or K3 is a science, art and technique to be applied in working so that the work carried out is free from risks that can result in health problems, work accidents, explosions, burning, and air pollution in the workplace. Or the essence of Occupational Health and Safety or K3 definition is accident prevention (Silaban, 2017). Work Safety described in RI Law No. 1 of 1970 that the protection of safety provided is not only aimed at workers but also for all people who are on the job site and that all equipment / machinery must be in good condition and used with care. According to RI Law No. 17 of 2008 the crew of the ship is a person who has a register book and is employed by the ship owner to carry out obligations based on his position.

The National Transportation Safety Committee (NTSC) recorded in Indonesia from 2010 to 2016 there were an increase in cases of shipping accidents each year with a total of 54 cases. This type of accident is dominated by burning / exploding 35 percent of collisions 31 percent drowning 24 percent foundered by six percent and others four percent. NTSC noted that throughout 2017 there was an increase in shipping accidents nearly doubled with 34 cases, where in 2016 there were only 18 accidents and the most types of accidents were the same as in previous years. 
The vital impact of a shipping accident is that many people are killed. Recorded in 2017 as many as 42 passengers died/lost two passengers injured (Media Maritim Online, 2018), in 2016 as many as 51 passengers died/lost 18 passengers were injured, in 2015 as many as 85 passengers died/lost two passengers injured, in 201422 passengers died/four passengers were injured, in 201365 passengers died/nine passengers were injured. Based on this data it can be seen that the death toll is still high, fluctuating and tends to increase from year to year (NTSC, 2016).

In 2016, Tanjungpinang there had been an accident with a type of boat accident reversed and resulted in the death of 10 passengers died, two passengers were injured, and five passengers were missing (KNKT, 2016). Data from Tanjungpinang Class II Port Health Office (KKP) In 2018 there were two cases of accidents, the first in May with a type of fire accident and no fatalities, the second in June with the type of wreck sinking with one person dead.

\section{Review of Literature}

\subsection{Unsafe Action}

Unsafe action is a process of activity without regard to the element of safety thus the possibility of work accidents will occur (Ramli, 201). Unsafe action is a mistake due to the inability of workers to carry out criteria and stages of work in accordance with existing standards to result in work accidents, such as: not having the authority or qualifications to do work, using damaged equipment, wrong or not using self-protection equipment and so forth. (Winarsunu, 2008).

Types of unsafe actions. According to Silaban (2017), the types of unsafe actions consist of the following:

1. Doing work that is not his job / without orders.

2. Making safety devices that are not his job.

3. Running the engine at dangerous speed.

4. Lack of knowledge and skills.

5. Not wearing / wrong wearing personal protective equipment.

6. Error / failure to give warning or security.

7. Ignore the warning signs.

8. Wearing damaged equipment.

9. Using inadequate equipment.

10. Wrong loading / placement.

11. Lifting the wrong way.

12. Placement of something that is inadequate.

13. Inappropriate work position.

14. Repairing equipment that is moving.

15. Working while joking / joking.

16. Working out of concentration.

17. Working while smoking / eating.

18. Drinking alcoholic beverages.

19. Using illegal drugs.

20. Subtle bodily defects.

21. Fatigue and lethargy.

\subsection{Training}

Training is an effort to improve or maintain the ability of employees to produce effective work (Bangun, 2012). According to Sihombing (2015) training is an effort to increase the capacity 
of employees / workers in order to have better skills in terms of skills, knowledge and professionalism in working to add expertise in achieving company goals.

Technical skills were initially only given to workers or operational / field employees. But now training is also intended for administrative and managerial workers and even every employee in the company. For job transfers and longtime employees training is provided as a basis for adjustment and improvement. Thus it can be concluded that training provides benefits for employees and the company. Employees who have a greater workload and responsibility must attend training. The same thing must also be given to workers who experience displacement because workers will find it difficult to recognize and carry out their work (Bangun, 2012).

Training must use a rational training process, the standard is still a five-step ADDIE (analysis-design-develop-implement-evaluate) training process, namely training needs analysis, overall training program design, developing subjects, implementing training, and evaluating eye effectiveness the lesson (Dessler, 2016).

There are two training techniques namely off the job training method and on the job training method. Information presentation method with the aim of teaching various skills, concepts, and attitudes, to trainees is the off the job training method. Whereas the direct supervision method from professional trainers about the work of the trainees is on the job training method (Sihombing, 2015). According to Mathis and Jackson in Sihombing (2015) training can be designed and differentiated based on the desired goals, including:

1. Based on needs: Training for all new employees as an orientation to meet various applicable and required legal requirements.

2. Based on technical / work: Strengthening so employees can carry out their responsibilities and obligations properly.

3. Based on problem solving: In organizational work training is also intended to improve relationships and deal with interpersonal and operational issues.

4. Based on innovative and development: To improve organizational and individual capabilities in the future it is necessary to prepare focus in the long run.

\subsection{Definition of the Crew}

According to Law No. 17 of 2008 Ship Crew is a person who works or is employed on a ship by the owner or operator of a ship to carry out duties on the ship in accordance with his position stated in the register book. The crew consists of several parts each part has its own duties and responsibilities, the division of crew based on activities on the ship that is the deck and engine.

The existing organizational structure of ships is not a standard structure, because each ship's organizational structure can differ depending on the type, function and condition of the ship. Several types of crews' positions and responsibilities (Sasono, et al, 2014):

1. Captain: is the person responsible for carrying ships sailing from port to port or from place to place safely, safely to the destination of the passengers and all their cargo.

2. Mualim: The preacher is the person who is responsible for the deck and helps the skipper manage all the work and becomes a substitute for the skipper when the skipper is unable to do his work. The chief officer is also tasked with maintaining existing navigation and safety equipment.

3. KKM (Engine Room Head): Responsible for all the engines on board, be it a main engine, auxiliary engines, pump engines, crane engines, lifeboats, steering engines, freezer engines, etc. 
4. Machinist: The crew of the ship is tasked with helping the KKM run and maintain the main engine, auxiliary engine, or pump engine on the ship.

5. Oiler: The crew of the ship is tasked with helping KKM run machine tools, especially in lubricating moving equipment.

6. Helmsman (Able Bodied Seaman/AB): The crew is in charge of observing deck hours, measuring air and sea phenomena, receiving signal transmissions, raising / lowering flags, sending messages, and so on.

7. Ordinary Seaman / OS: The crew in charge of carrying out the calculation of the load, maintain the cleanliness of the ship, arrange deck equipment, and guard duty at the port.

\section{Research Method}

This type of research is an analytical survey using cross sectional design aimed at explaining a situation by analyzing the relationship between individual factors and work factors with unsafe action on the crew of passenger ships in Tanjung Pinang City. The study was conducted at the port of Sri Bintan Pura in Tanjung Pinang City. When the research will be carried out in October 2018 until June 2019.

The population in this study is the crew of passenger ships with the position of Captain, Mualim, KKM (Head of Engine Room), and Oiler in the port of Sri Bintan Pura Tanjungpinang City with the destination of Tanjungpinang to Batam. Shipping from Tanjungpinang to Batam consists of two shipping agents namely PT. Baruna Jaya and PT. Marinatama Gemanusa. The total population of 46 people, with the distribution of the crew as follows:

Table 1. Number of Crew Distribution

\begin{tabular}{lcccc}
\hline \multicolumn{1}{c}{ Ship name } & Captain & Mualim & KKM & Oiler \\
\hline PT. Baruna Jaya & & & & \\
MV. Oceana 1 & 1 & 1 & 1 & 1 \\
MV. Oceana 3 & 1 & 1 & 1 & 1 \\
MV. Oceana 7 & 1 & 1 & 1 & 1 \\
MV. Oceana 9 & 1 & 1 & 1 & 1 \\
MV. Oceana 10 & 1 & 1 & 1 & 1 \\
MV. Ocean Dragon 3 & 1 & 1 & 1 & 1 \\
MV. Ocean Dragon 6 & 1 & 1 & 1 & 1 \\
\hline & & & & 1 \\
\hline MV. Oceana 10 & 1 & 1 & 1 & 1 \\
MV. Ocean Dragon 3 & 1 & 2 & 1 & 1 \\
MV. Ocean Dragon 6 & 1 & 1 & 1 & 1 \\
PT. Marinatama Gemanusa & & & & 1 \\
MV. Arena 3 & 1 & 1 & 1 & 1 \\
MV. Marina Baru & 1 & 1 & 1 & 1 \\
MV. Marina Express 8 & 1 & 1 & 1 & 1 \\
MV. Sabang Marindo VII & 1 & 2 & 1 & \\
\hline$\quad$ Total & 11 & 13 & 11 & 11 \\
\cline { 2 - 5 }
\end{tabular}

In this study in determining the sample using a total sampling technique in which the entire population is used as a research sample. However, at the time of the study there was one crew member who was not willing to be a respondent in the study so that the total sample of the study was 45 people. 
Table 2. Validity and Reliability Test of the Knowledge Questionnaire

\begin{tabular}{cccc}
\hline Questionnaire's & Validity Test & Reliability Test & \multirow{2}{*}{ r Tabel } \\
\cline { 2 - 3 } Item & r count & Cronbach's Alpha & 0,482 \\
1 & 0,584 & 0,827 & \\
3 & 0,526 & & \\
4 & 0,556 & & \\
5 & 0,599 & & \\
6 & 0,599 & & \\
7 & 0,656 & & \\
8 & 0,599 & & \\
9 & 0,482 & & \\
10 & 0,487 & & \\
11 & 0,584 & & \\
12 & 0,867 & & \\
\hline
\end{tabular}

The table above shows the value of $\mathrm{r}$ table of 0.482 at a significant 5 percent with a twotailed test and $n=17$. Then it can be concluded that the knowledge questionnaire is valid because it has a calculated $r$ value and Cronbach's Alpha $>$ of the $r$ table value.

Table 3. Validity and Reliability Test of the Motivation Questionnaire

\begin{tabular}{cccc}
\hline Questionnaire's & Validity Test & Reliability Test & \multirow{2}{*}{ r Tabel } \\
\cline { 2 - 3 } Item & r count & Cronbach's Alpha & 0,482 \\
2 & 0,595 & 0,746 & \\
3 & 0,521 & & \\
4 & 0,494 & & \\
5 & 0,570 & & \\
6 & 0,521 & & \\
7 & 0,586 & & \\
8 & 0,761 & & \\
9 & 0,565 & & \\
10 & 0,494 & & \\
\hline
\end{tabular}

The table above shows the value of $\mathrm{r}$ table of 0.482 at a significant 5 percent with a twotailed test and $n=17$. Then it can be concluded that the motivation questionnaire is valid because it has a calculated $r$ value and Cronbach's Alpha $>$ of the $r$ table value.

Table 4. Validity and Reliability Test of the Supervision Questionnaire

\begin{tabular}{cccc}
\hline Questionnaire's & Validity Test & Reliability Test & \multirow{2}{*}{ r Tabel } \\
\cline { 2 - 3 } Item & r count & Cronbach's Alpha & 0,482 \\
2 & 0,523 & 0,597 & \\
3 & 0,766 & & \\
4 & 0,564 & & \\
5 & 0,486 & & \\
6 & 0,676 & & \\
\hline
\end{tabular}


Table 5. Validity and Reliability Test of the Unsafe Action Questionnaire

\begin{tabular}{cccc}
\hline Questionnaire's & Validity Test & Reliability Test & \multirow{2}{*}{ r Tabel } \\
\cline { 2 - 3 } Item & r count & Cronbach's Alpha & 0,482 \\
\hline 1 & 0,716 & 0,858 & \\
3 & 0,570 & & \\
4 & 0,580 & & \\
5 & 0,499 & & \\
6 & 0,499 & & \\
7 & 0,499 & & \\
8 & 0,625 & & \\
9 & 0,625 & & \\
10 & 0,663 & & \\
11 & 0,566 & & \\
12 & 0,566 & & \\
13 & 0,546 & & \\
14 & 0,611 & & \\
15 & 0,611 & & \\
\hline
\end{tabular}

From the table above it is known that the value of $\mathrm{r}$ table is 0.482 at a significant 5 percent with a two-tailed test and $\mathrm{n}=17$. It can be concluded that the unsafe action questionnaire is valid because it has a calculated $r$ value and Cronbach's Alpha $>$ of the $r$ table value.

Table 6. The Aspects of Variable Measurement

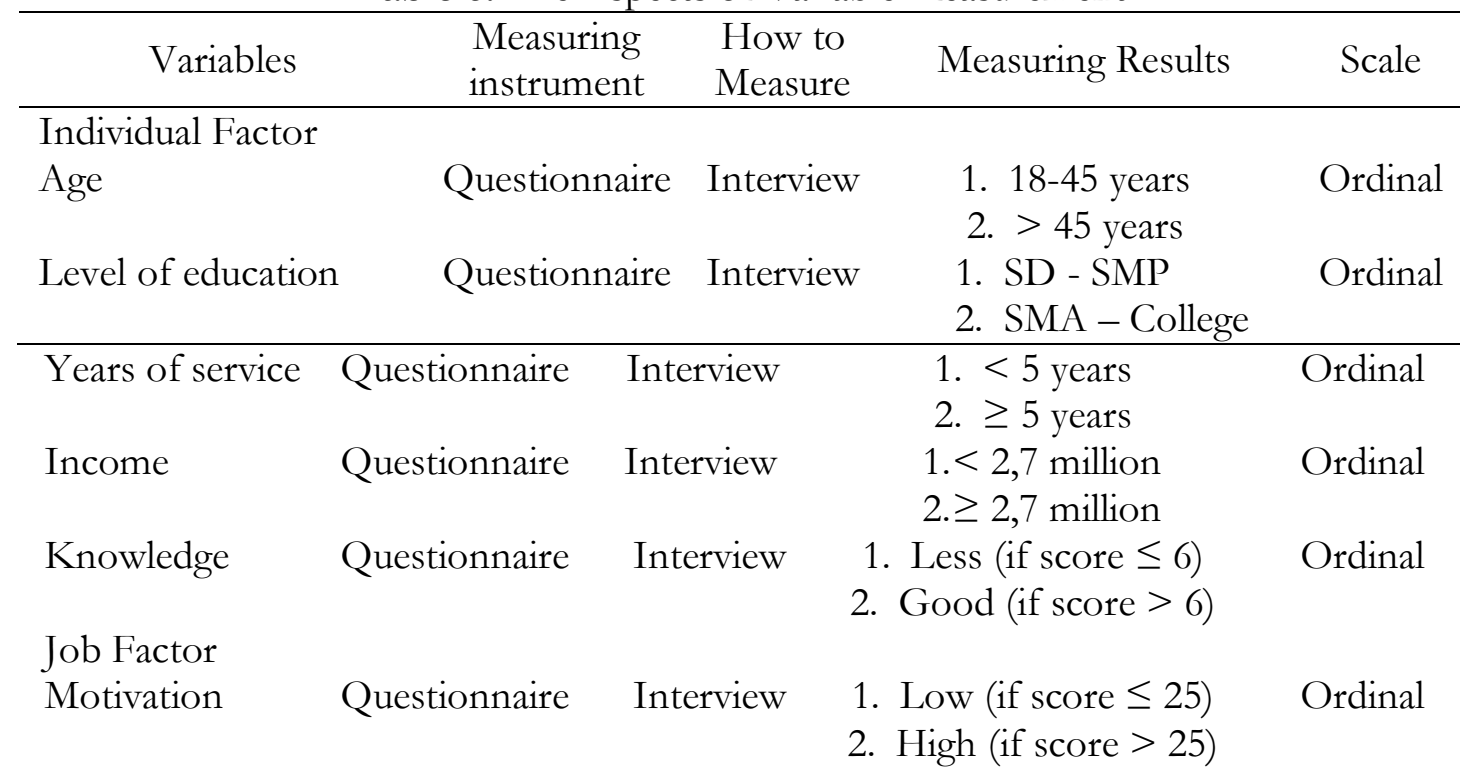

The knowledge variable questionnaire consisted of 12 questions, the highest value was given a weighting of 1 (one) and the lowest value was given a weighting of 0 (zero). Then calculated using the Guttman scale, namely:

Score interval $=$ (highest score - lowest score) $/$ category

$$
\begin{aligned}
& =(12-0) / 2 \\
& =6
\end{aligned}
$$

Standard score $=$ highest score - interval score

$$
\begin{aligned}
& =12-6 \\
& =6
\end{aligned}
$$


From the above calculation, if the total score of answers $\leq 6$ is categorized as less and if the total score of answers $>6$ is categorized as good.

Motivational variables adopted a questionnaire that had been used previously by Syamtinningrum (2017) and modified according to research needs. The questionnaire consisted of 10 questions using a Likert scale for positive questions strongly disagreed choice (STS) rated 1 (one), disagree (TS) given a value of 2 (two), agree (S) given a value of 3 (three), and Strongly agree (SS) are given a value of 4 (four) while the negative choice questions strongly disagree (STS) are given a value of 4 (four), disagree (TS) are given a value of 3 (three), agree (S) are given a value of 2 (two), and strongly agree (SS) given a value of 1 (one). Then the calculation determines the categories, namely:

Score interval $=$ (highest score - lowest score) $/$ category

$$
=(40-10) / 2
$$

$$
=15
$$

Standard score $=$ highest score - interval score

$$
\begin{aligned}
& =40-15 \\
& =25
\end{aligned}
$$

From the above calculation, if the total score of answers $\leq 25$ is categorized low and if the total score of answers $>25$ is categorized high.

The training variable questionnaire consisted of six questions for the highest value given a weighting of 1 (one) and the lowest value given a weighting of 0 (zero). Then calculated using the Guttman scale, namely:

Score interval $=$ (highest score - lowest score) $/$ category

$$
\begin{aligned}
& =(6-0) / 2 \\
& =3
\end{aligned}
$$

Standard score $=$ highest score - interval score

$$
=6-3
$$$$
=3
$$

From the above calculation, if the total score of answers $\leq 3$ is categorized as less and if the total score of answers $>3$ is categorized as good.

The unsafe action variable questionnaire consisted of 15 questions for the highest value given a weighting of 1 (one) and the lowest value given a weighting of 0 (zero). Then calculated using the Guttman scale, namely:

Score interval $=$ (highest score - lowest score) $/$ category

$$
\begin{aligned}
& =(15-0) / 2 \\
& =7.5
\end{aligned}
$$

Standard score $=$ highest score - interval score

$$
\begin{aligned}
& =15-7.5 \\
& =7.5
\end{aligned}
$$

From the above calculation, if the total score of $\leq 7.5$ is categorized as low and if the total score of answers $>7.5$ is categorized as high. 


\section{Discussion}

Univariate analysis was carried out to see the description of the characteristics of the respondents of the independent and dependent variables.

Table 7. Distribution of Knowledge Frequency

\begin{tabular}{|c|c|c|c|c|}
\hline \multirow{2}{*}{ Knowledge } & \multicolumn{2}{|c|}{ Wrong } & \multicolumn{2}{|c|}{ Right } \\
\hline & $\mathrm{n}$ & $\%$ & $\mathrm{n}$ & $\%$ \\
\hline $\begin{array}{l}\text { Occupational safety and health are efforts to } \\
\text { prevent accidents and diseases caused by } \\
\text { work }\end{array}$ & 11 & 24,4 & 34 & 75,6 \\
\hline $\begin{array}{l}\text { Maintaining cleanliness, beauty and order in } \\
\text { the workplace is the goal of the application } \\
\text { of occupational safety and health }\end{array}$ & 42 & 93,3 & 3 & 6,7 \\
\hline $\begin{array}{l}\text { Accidents that occur when heading to work } \\
\text { are not included work accidents }\end{array}$ & 31 & 68,9 & 14 & 31,1 \\
\hline $\begin{array}{l}\text { The benefit of Personal Protective Equipment } \\
\text { (PPE) is to protect workers from hazards } \\
\text { in the workplace }\end{array}$ & 13 & 28,9 & 32 & 71,1 \\
\hline $\begin{array}{l}\text { Personal protective equipment (PPE) is used } \\
\text { when seen by a supervisor or supervisor }\end{array}$ & 17 & 37,8 & 28 & 62,2 \\
\hline Joking while working is common & 22 & 48,9 & 23 & 51,1 \\
\hline $\begin{array}{l}\text { Vibration, noise and heat are included in } \\
\text { physical hazards }\end{array}$ & 20 & 44,4 & 25 & 55,6 \\
\hline Excessive noise can cause hearing loss & 4 & 8,9 & 41 & 91,1 \\
\hline $\begin{array}{l}\text { At work the availability and completeness of } \\
\text { the contents of the first aid kit is very } \\
\text { important }\end{array}$ & 4 & 8,9 & 41 & 91,1 \\
\hline $\begin{array}{l}\text { Machinery, materials and equipment used } \\
\text { while working can cause hazards in the } \\
\text { workplace }\end{array}$ & 19 & 42,2 & 26 & 57,8 \\
\hline $\begin{array}{l}\text { Every worker must have an initial and } \\
\text { periodic health check }\end{array}$ & 3 & 6,7 & 42 & 93,3 \\
\hline $\begin{array}{l}\text { Every work accident must be recorded and } \\
\text { reported }\end{array}$ & 15 & 33,3 & 30 & 66,7 \\
\hline
\end{tabular}

Based on data table 7 regarding the knowledge of respondents answered

Table 8. Distribution of Motivation Frequency

\begin{tabular}{|c|c|c|c|c|c|c|c|c|}
\hline \multirow{2}{*}{ Motivation } & \multicolumn{2}{|c|}{ STS } & \multicolumn{2}{|c|}{ TS } & \multicolumn{2}{|c|}{ S } & \multicolumn{2}{|c|}{ SS } \\
\hline & $\mathrm{n}$ & $\%$ & $\mathrm{n}$ & $\%$ & $\mathrm{n}$ & $\%$ & $\mathrm{n}$ & $\%$ \\
\hline $\begin{array}{l}\text { I like and enjoy working as a } \\
\text { crew }\end{array}$ & - & - & - & - & 38 & 84,4 & 7 & 15,6 \\
\hline $\begin{array}{l}\text { I feel satisfied with the salary / } \\
\text { wages that I receive now }\end{array}$ & 1 & 2,2 & 17 & 37,8 & 26 & 57,8 & 1 & 2,2 \\
\hline The day off is still lacking & 2 & 4,4 & 6 & 13,3 & 27 & 60,0 & 10 & 22,2 \\
\hline $\begin{array}{l}\text { I am not bothered by the } \\
\text { status of contract work } \\
\text { (PKL) }\end{array}$ & 3 & 6,7 & 14 & 31,1 & 27 & 60,0 & 1 & 2,2 \\
\hline $\begin{array}{l}\text { I got health insurance from the } \\
\text { company }\end{array}$ & 3 & 6,7 & 6 & 13,3 & 30 & 66,7 & 6 & 13,3 \\
\hline
\end{tabular}


Bosses / skippers always give direction and supervis while working

Safety equipment, equipment, and PPE related to work are available on the ship

At work, disputes between crew members often occur

$-\quad-3$

$3 \quad 6,7$

33

$73,3 \quad 9$

20,0

$-\quad-6$

$13,3 \quad 33$

$73,3 \quad 6$

13,3

$\begin{array}{rrrrrrrr}6 & 13, & 22 & 48,9 & 13 & 28,9 & 4 & 8,9\end{array}$

The company does not sanction lazy workers o make mistakes

Table 9. Distribution of Unsafe Action Frequency

\begin{tabular}{|c|c|c|c|c|}
\hline \multirow{2}{*}{ Unsafe Action } & \multicolumn{2}{|c|}{ Never } & \multicolumn{2}{|c|}{ Ever } \\
\hline & $\mathrm{n}$ & $\%$ & $\mathrm{n}$ & $\%$ \\
\hline $\begin{array}{l}\text { Doing the work of others on their own } \\
\text { initiative / without orders }\end{array}$ & 3 & 6,7 & 42 & 93,3 \\
\hline $\begin{array}{l}\text { Run work equipment or machines at a speed } \\
\text { that is not according to procedure }\end{array}$ & 42 & 93,3 & 3 & 6,7 \\
\hline Doing work without based on SOP & 39 & 86,7 & 6 & 13,3 \\
\hline Using damaged work equipment & 32 & 71,1 & 13 & 28,9 \\
\hline $\begin{array}{l}\text { Do not use personal protective equipment / } \\
\text { safety equipment in full in accordance } \\
\text { with applicable regulations }\end{array}$ & 29 & 64,4 & 16 & 35,6 \\
\hline $\begin{array}{l}\text { Placing work equipment in any place both at } \\
\text { work and after work }\end{array}$ & 25 & 55,6 & 20 & 44,4 \\
\hline $\begin{array}{l}\text { Repair or carry out maintenance of work } \\
\text { equipment that is in motion }\end{array}$ & 27 & 60,0 & 18 & 40,0 \\
\hline $\begin{array}{l}\text { Joking around at work (shocking coworkers, } \\
\text { yelling or ignorant at coworkers, etc.) }\end{array}$ & 10 & 22,2 & 35 & 77,8 \\
\hline Sailing during bad weather & 6 & 13,3 & 39 & 86,7 \\
\hline $\begin{array}{l}\text { Do not turn off equipment or work } \\
\text { machines that are not used }\end{array}$ & 34 & 75,6 & 11 & 24,4 \\
\hline $\begin{array}{l}\text { Consuming alcohol and / or illegal drugs } \\
\text { before, during and after work }\end{array}$ & 44 & 97,8 & 1 & 2,2 \\
\hline $\begin{array}{l}\text { Load excessive loads, for example raising } \\
\text { passengers over capacity }\end{array}$ & 24 & 53,3 & 21 & 46,7 \\
\hline Work while smoking / eating & 9 & 20,0 & 36 & 80,0 \\
\hline $\begin{array}{l}\text { Not conducting periodic checks on the } \\
\text { equipment or machinery used }\end{array}$ & 36 & 80,0 & 9 & 20,0 \\
\hline Work when the body is unwell & 10 & 22,2 & 35 & 77,8 \\
\hline
\end{tabular}

Based on data from table 9 regarding Unsafe Action

Table 10. Frequency Distribution of Individual Factors (Age, Education Level, Years of Service, Income, Knowledge), Employment Factors (Motivation,) and Unsafe Action

\begin{tabular}{ccc}
\hline \multicolumn{1}{c}{ Variables } & Total (n) & Percentage \\
\hline Safety Facilities & & \\
Incomplete & 3 & 27,3 \\
complete & 8 & 72,7
\end{tabular}

Aged 
$18-45$ years

$>45$ years

Education Level

Not over from SD - SD - SMP

SMA - College

Years of Service

$<5$ years

$\geq 5$ years

Income

$<2,7$ million

$\geq 2,7$ million

Knowledge

Less

Good

Motivation
31

14

4

41

25

20

6

39

19

26

18

27
68,9

31,1

8,9

91,1

55,6

44,4

13,3

86,7

42,2

57,8

Low

High

Total

45

40,0

60,0

100,0

Based on the table above overview of safety facilities

\section{Bivariate Analysis}

Table 11. The Relationship between Individual Factors (Age, Education Level, Years of Service, Income, Knowledge) and Employment Factors (Motivation, Training, Supervision) with Unsafe Action on Passenger Ship Crews in Tanjung Pinang City

\begin{tabular}{|c|c|c|c|c|c|c|c|c|}
\hline \multirow{3}{*}{ Variables } & \multicolumn{6}{|c|}{ Unsafe Action } & \multirow{3}{*}{$p$ value } & \multirow{3}{*}{$\mathrm{RP}$} \\
\hline & \multicolumn{2}{|c|}{ High } & \multicolumn{2}{|c|}{ Low } & \multicolumn{2}{|c|}{ Total } & & \\
\hline & $\mathrm{n}$ & $\%$ & $\mathrm{n}$ & $\%$ & $\mathrm{n}$ & $\%$ & & \\
\hline Age & & & & & & & & \\
\hline $18-45$ years & 16 & 51,6 & 15 & 48,4 & 31 & 100,0 & 0,322 & 1,920 \\
\hline$>45$ years & 5 & 35,7 & 9 & 64,3 & 14 & 100,0 & & \\
\hline Education Level & & & & & & & & \\
\hline SD - SMP & 4 & 100,0 & 0 & 0,0 & 4 & 100,0 & 0,040 & \\
\hline SMA - College & 17 & 41,5 & 24 & 58,5 & 41 & 100,0 & & \\
\hline Years of Service & & & & & & & & \\
\hline$<5$ years & 16 & 64,0 & 9 & 36,0 & 25 & 100,0 & 0,009 & 5,333 \\
\hline $\begin{array}{l}\geq 5 \text { years } \\
\text { Income }\end{array}$ & 5 & 25,0 & 15 & 75,0 & 20 & 100,0 & & \\
\hline$<2,7$ million & 3 & 50,0 & 3 & 50,0 & 6 & 100,0 & 1,000 & 1,167 \\
\hline $\begin{array}{l}\geq 2,7 \text { million } \\
\text { Knowledge }\end{array}$ & 18 & 46,2 & 21 & 53,8 & 39 & 100,0 & & \\
\hline Less & 13 & 68,4 & 6 & 30,8 & 19 & 100,0 & 0,012 & 4,875 \\
\hline $\begin{array}{l}\text { Good } \\
\text { Motivation }\end{array}$ & 8 & 30,8 & 18 & 69,2 & 26 & 100,0 & & \\
\hline Low & 13 & 72,2 & 5 & 27,8 & 18 & 100,0 & 0,005 & 6,175 \\
\hline High & 8 & 29,6 & 19 & 70,4 & 27 & 100,0 & & \\
\hline
\end{tabular}

\section{Multivariate Analysis}

To find out the most dominant independent variable with unsafe action on the crew of passenger ships in Tanjung Pinang, a multivariate analysis was performed using a multiple logistic regression test. 
Selection of variables as candidates. In this study there are eight variables thought to be related to unsafe action, namely individual factors including age, education level, years of service, income, knowledge and work factors including motivation, training, and supervision. For the selection of variables to be included in the prediction model of multiple logistic regression tests, the eight independent variables are first performed bivariate analysis with the dependent variable, namely unsafe action. After going through bivariate analysis, variables with a $\mathrm{P}$ value $<0.25$ are made as candidate variables that will be included in the multivariate analysis. The results of the bivariate analysis between the independent variables and the dependent variables can be seen in table 12.

Table 12. Selection of Model Candidates for Multivariate Analysis

\begin{tabular}{|c|c|}
\hline Variable & $\mathrm{P}$ value \\
\hline \multicolumn{2}{|l|}{ Individual Factors } \\
\hline Age & 0,322 \\
\hline Education Level & $0,040 *$ \\
\hline Years of Service & $0,009 *$ \\
\hline Income & 1,000 \\
\hline Knowledge & $0,012^{*}$ \\
\hline \multicolumn{2}{|l|}{ Job Factor } \\
\hline Motivation & $0,005^{*}$ \\
\hline Training & $0,007 *$ \\
\hline Supervision & 0,538 \\
\hline
\end{tabular}

Based on the table above there are five variables which $\mathrm{P}$ value $<0.25$, namely the level of education, years of service, knowledge, motivation, and training. Thus, these variables enter into the multiple logistical test prediction model.

Modeling the most dominant factor. In this modeling all candidate variables are analyzed simultaneously. Variables are analyzed using the Backward technique by entering all the variables, then SPSS will eliminate one by one the insignificant variables and then process again without these insignificant variables, continuously, so that a model is found that is appropriate to represent the model.

Table 13. Multivariate Analysis Results of Multiple Logistic Regression between Independent Variables (Education Level, Years of Service, Knowledge, Motivation, and Training) and Dependent Variables (Unsafe Action)

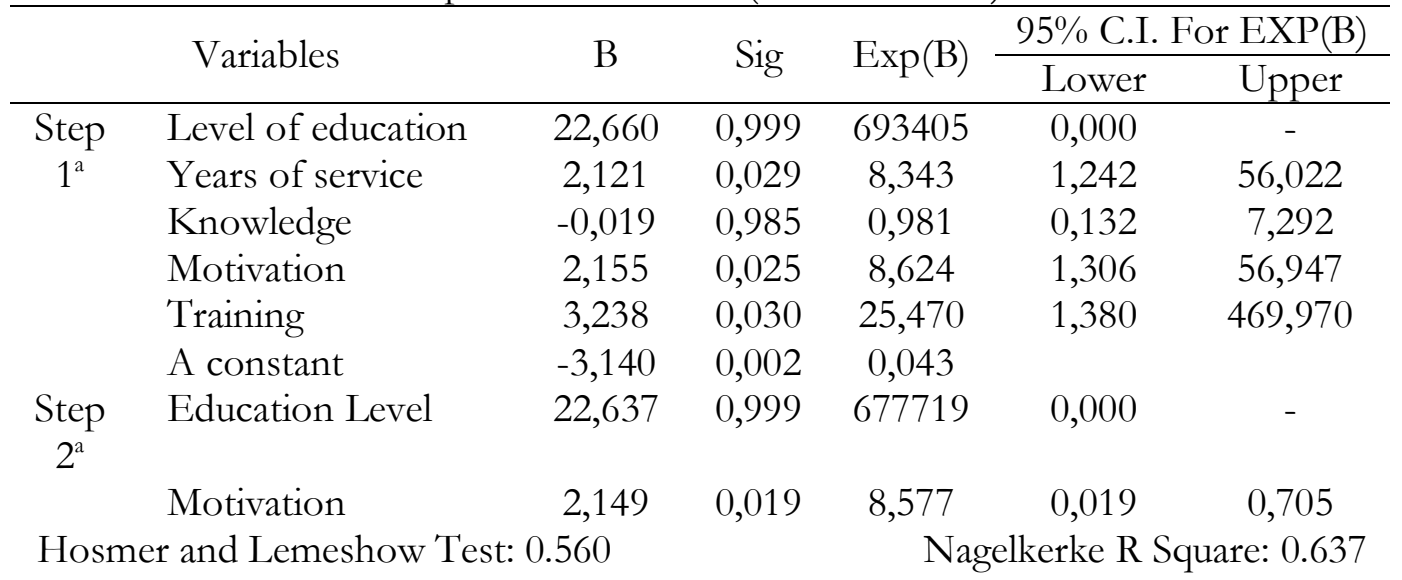


Based on the results of the study indicate that there is a significant relationship between motivation and unsafe action. In the multivariate test, it is known that motivation variable has an influence on unsafe action with $\mathrm{p}$ value $=0.019$ and $\exp (\mathrm{B})$ value of 8.577 , which means that the motivation variable in the low category will cause unsafe action to be high by 8.577 times compared to the high motivation category.

\section{Conclusion}

Based on the results of the study the majority of respondents classified as young, have a high level of education, a new tenure, have a high income, good knowledge of occupational health and safety, high motivation, and unsafe action. Based on the bivariate analysis obtained levels of education, years of service, knowledge, motivation, related to unsafe action.

\section{References}

Alamsyah, D., \& Ratna, M. (2015). Pilar dasar ilmu kesehatan masyarakat. Yogyakarta: PT. Nuha Medika.

Anizar. (2009). Teknik keselamatan dan kesehatan kerja industri. Yogyakarta: PT. Graha Ilmu.

Bancin, A.M. (2017). Faktor-faktor yang memengaruhi tindakan tidak aman (unsafe action) pada pekerja di PT. Kharisma Cakranusa Rubber Industry Tahun 2016 (Skripsi, Universitas Sumatera Utara). Diakses dari http://repositori.usu.ac.id/handle/123456789/1788

Bangun, W. (2008). Intisari manajemen. Bandung: PT. Refika Aditama.

Bangun, W. (2012). Manajemen sumber daya manusia. Jakarta: Erlangga.

BPS Indonesia. (2018). Statistik Indonesia Indonesia 2018. Dikases dari https://www.bps.go.id/publication/2018/07/03/5a963c1ea9b0fed6497d0845/statistikindonesia-2018

BPS Kepri. (2017). Provinsi Kepulauan Riau Dalam Angka 2017. Dikases dari https://kepri.bps.go.id/publication/2017/08/11/8d778cc5c7e221a58020a580/provinsikepulauan-riau-dalam-angka-2017

Buntarto. (2015). Panduan praktis keselamatan dan kesehatan kerja untuk industri. Yogyakarta: PT. Pustaka Baru Press.

Chinonyerem, N.T., Calistus, I., Geraldine, O., \& Ntor-Ue, M. (2017). Analysis of vessel-based marine accidents and the economic risks to Nigeria. Journal of Water Resources and Ocean Science, 6(6), 72.

Dahlan, M.S. (2009). Besar sampel dan cara pengambilan sampel dalam penelitian kedokteran dan kesehatan. Jakarta : Salemba Medika.

Dessler, G. (2016). Manajemen sumber daya manusia. Jakarta: Salemba Empat.

Disnakertrans Kepri. (2017). Analisis Ketenagakerjaan Provinsi Kepri 2017. Diakses dari https://disnakertrans.kepriprov.go.id/Welcome/download-analisis-ketenagakerjaanprovinsi-kepri-2017

Hafrida, E. (2014). Pengaruh faktor personal dan manajemen K3 terhadap tindakan tidak aman (unsafe action) pada pekerja di PT. Inti Benua Perkasatama Dumai (Tesis, Universitas Sumatera Utara). Diakses dari http://repository.usu.ac.id/handle/123456789/49527

Halimah, S. (2010). Faktor-faktor yang mempengaruhi perilaku aman karyawan di PT. SIM PLANT Tambun II Tahun 2010 (Skripsi, Universitas Islam Negeri Syarif Hidayatullah Jakarta). Diakses

dari http://repository.uinjkt.ac.id/dspace/bitstream/123456789/627/1/92636siti $\% 20$ halimah-fkik.pdf

Kadarisman, M. (2014). Manajemen pengembangan sumber daya manusia. Jakarta: Rajawali Pers.

Kadarisman, M. (2016). Manajemen kompensasi. Jakarta: PT. Raja Grafindo Persada. 
KNKT. (2009). Kajian Analisis Trend Kecelakaan Transportasi Laut Tahun 2003-2008. Diakses dari

http://knkt.dephub.go.id/knkt/ntsc_maritime/Laut/Publications/Laporan\%20Analisis $\% 20$ Trend $\% 20$ Kecelakaan\%20Laut $\% 202003-2008$.pdf

KNKT. (2016). Media Release KNKT : Data Investigasi Kecelakaan Pelayaran. Diakses dari http://knkt.dephub.go.id/knkt/ntsc_home/Media_Release/

Media\%20Release\%20KNKT\%202016/Media\%20Release\%202016\%20$\% 20 \mathrm{IK} \% 20$ Pelayaran $\% 2020161130 . p d f$

Lady, L., Marliana, P., \& Umyati, A. (2014). Kajian kecelakaan kapal di pelabuhan Banten menggunakan human factors analysis and classification system (HFACS). Jurnal Rekayasa Sistem Industri, 3(2), 46-52.

Lasse, D.A. (2014). Keselamatan pelayaran di lingkungan teritorial pelabuhan dan pemanduan kapal. Jakarta: PT. Raha Grafindo Persada.

Markle, W.H., Melanie, A., Fisher, R.A., \& Smego, Jr. (2007). Understanding global health. Amerika Serikat: The McGraw-Hill Companies.

Maulana, H.D.J. (2014). Promosi kesehatan. Jakarta: EGC.

Media Maritim Online. (2018). KNKT Investigasi 34 Kecelakan Kapal di Tahun 2017. Diakses 30 Januari 2019, dari https://www. emaritim.com/2018/01/knkt-investigasi-34kecalakan-kapal-di.html

Mokhtari, A., \& Khodadadi, H.R. (2013). An empirical survey on the role of human error in marine incidents. TransNav: International Journal on Marine Navigation and Safety of Sea Transportation, 7(3).

Mubarak, W.I., Nurul, C., Khoirul, R., \& Supradi. (2012). Promosi kesehatan. Yogyakarta: PT. Graha Ilmu.

Mutholib, A. (2019). Kajian fasilitas keselamatan kapal pada lintas penyebrangan 35 Ilir-Muntok. Warta Penelitian Perhubungan, 25(2), 140-146.

Nasir, A., Abdul, M., \& Ideputri. (2011). Buku ajar metodologi penelitian kesehatan : Konsep Pembuatan Karya Tulis dan Tesis Untuk Mahasiswa Kesehatan. Yogyakarta: Nuha Medika

Nawawi, H.H. (2016). Manajemen sumber daya manusia. Yogyakarta: UGM Press

Nkem, A.N., Hassim, \& Kidam, K. (2015). Relationship between unsafe acts/condition and accidents in construction company in Nigeria. Jurnal Teknologi (Sciences \& Engineering), 75(6), 73-77.

Noor, J. (2015). Penelitian ilmu manajemen: Tinjauan filosofis dan praktis. Jakarta: Prenada media Group.

Notoatmodjo, S. (2012). Promosi kesehatan dan perilaku kesehatan. Jakarta: PT. Rineka Cipta.

Notoatmodjo, S. (2016). Metodologi penelitian kesehatan (Edisi Revisi). Jakarta: PT. Rineka Cipta.

Noviandi, A.A.R., Hartanti, R.I. \& Ningrum, P.T. (2017). Faktor yang mempengaruhi perilaku mengemudi tidak aman pada sopir bus trayek Jember Kencong Lumajang. Jurnal Kesehatan, 5(2), 58-66.

Nurhasanah, N., Joni, A., \& Shabrina, N. (2015). Persepsi crew dan manajemen dalam penerapan ISM Code bagi keselamatan pelayaran dan perlindungan lingkungan laut. Proceeding SENDI_U.

Oluseye, O.O., \& Ogunseye, O.O. (2016). Human factors as determinants of marine accidents in maritime companies in Nigeria. Journal of Maritime Research, 13(3).

Othman, M. K., Abdul, N. S., \& Fadzil, M. N. (2016). Determining The Contribution of Distraction Factors on Seafarers Using a Systematic Average Rating Value. Journal of Maritime Research, 13(3).

Özdemir, Ü., Altinpinar, İ., \& Demirel, F.B. (2018). A MCDM approach with fuzzy AHP 
method for occupational accidents on board. TransNav: International Journal on Marine Navigation and Safety of Sea Transportation, 12.

Peraturan Menteri Perhubungan RI No. 25 Tahun 2015 tentang Standar Keselamatan Transportasi Sungai, Danau dan Penyebrangan.

Peraturan Menteri Tenaga kerja No. 03 Tahun 1998 tentang Tata Cara Pelaporan dan Pemeriksaan Kecelakaan.

Peraturan Pemerintah Republik Indonesia Nomor 51 Tahun 2002 tentang Perkapalan.

Peraturan Pemerintah Republik Indonesia Nomor 78 Tahun 2015 tentang Pengupahan.

Permana, A.S. (2014). Hubungan personal factor dengan unsafe action proses pemasangan pipa baja oleh PT. Putra Negara Surabaya. Jurnal ADLN, 4(2).

Pratama, A.K. (2015). Hubungan karakteristik pekerja dengan unsafe action pada tenaga kerja bongkar muat di PT. Terminal Petikemas Surabaya. The Indonesian Journal of Occupational Safety and Health, 4(1), 64-73.

Rahman, H. (2017). Penentuan faktor dominan penyebab kecelakaan kapal di Kesyahbandaran Utama Tanjung Priok. ALBACORE, 1(3), 277-284.

Ramli, S. (2010). Pedoman praktis manajemen bencana. Jakarta: PT. Dian Rakyat.

Riyanto, A. (2012). Aplikasi metodologi penelitian kesehatan (Cetakan ke-2). Yogyakarta: Nuha Medika.

Rivai, H., \& Furusho, M. (2013). Strategic Identification of Unsafe Actions That Characterize Accidents on Ships. Journal of Navigation and Port Research, 37(5), 499-509.

Safety Institute of Australia. (2012). Models of causation: Safety. Australia: OHS Body of Knowledge.

Sangaji, J., Jayanti, S. \& Lestantyo, D. (2018). Faktor-faktor yang berhubungan dengan perilaku tidak aman pekerja bagian lambung galangan kapal PT X. Jurnal Kesehatan Masyarakat (eJournal), 6(5), 563-571.

Saragih, F.R.P., Lubis, H.S. \& Tarigan, L. (2014). Faktor-faktor yang berhubungan dengan tindakan tidak aman pada pekerja lapangan PT. Telkom cabang Sidikalang Kabupaten Dairi Tahun 2014. Jurnal Kesehatan Masyarakat, 3(3).

Sasono, H.B., Soegiharto, Ec.H., \& Cahyono, R. (2014). Manajemen kapal niaga. Yogyakarta: ANDI OFFSET.

Setiarsih, Y., Setyaningsih, Y. \& Widjasena, B. (2017). Hubungan karakteristik pekerja, promosi K3, dan ketersediaan alat pelindung diri (APD) dengan perilaku tidak aman pada pekerja mechanical maintenance. Jurnal Kesehatan Masyarakat (e-Journal), 5(5), 424-433.

Sihombing, S. (2015). Manajemen sumber daya manusia. Jakarta: In media.

Silaban, G. (2017). Keselamatan dan kesehatan kerja. Medan.

Sinambela, L.P. (2018). Manajemen sumber daya manusia. Jakarta: Bumi Aksara.

Sirait, F.A. \& Paskarini, I. (2017). Analisis perilaku aman pada pekerja konstruksi dengan pendekatan behavior-based safety (studi di workshop PT. X Jawa Barat). The Indonesian Journal of Occupational Safety and Health, 5(1), 91-100.

Sholehudin, M. (2013). Hubungan personal factor dengan unsafe action di Unit X-PT. Baja X. Jurnal ADLN, 4(1).

Sucipto, C.D. (2014). Keselamatan dan kesehatan kerja. Yogyakarta: Gosyen Publishing, PT. Pustaka Baru Press.

Sugiyono. (2014). Metode penelitian kombinasi (mixed methods). Bandung: Alfabeta.

Suma'mur. (2009). Higiene perusahaan dan kesehatan kerja (Hiperkes). Jakarta: CV Sagung Seto.

Sumantri, A. (2011). Metodologi penelitian kesehatan. Jakarta: Prenada Media

Syamtinningrum. (2017). Pengembangan model hubungan faktor personal dan manajemen K3 terhadap tindakan tidak aman (unsafe action) pada pekerja PT. Yogya Indo Global (Tesis, Institut Teknologi Sepuluh Nopember Surabaya). Diakses dari http:/ / repository.its.ac.id/3315/1/2512204201\%20-Master_Theses.pdf 
Tarwaka, Bakri, S.H.A., \& Sudiajeng, L. (2004). Ergonomi untuk keselamatan, kesehatan kerja dan produktivitas. Surakarta: UNIBA PRESS.

Triwibowo, C., \& Mitha E.P. (2013). Kesehatan Lingkungan dan K3. Yogyakarta: PT. Nuha Medika.

Undang-undang Republik Indonesia nomor 1 Tahun 1970 tentang Keselamatan Kerja.

Undang-undang Republik Indonesia nomor 13 Tahun 2003 tentang Ketenagakerjaan.

Undang-undang Republik Indonesia nomor 17 Tahun 2008 tentang Pelayaran.

Wróbel, K., Montewka, J., \& Kujala, P. (2017). Towards the assessment of potential impact of unmanned vessels on maritime transportation safety. Reliability Engineering \& System Safety, 165(5), 155-169.

Winarsunu, T. (2008). Psikologi keselamatan kerja. Malang: UMM Press.

Yudhawan, Y.V. (2017). Hubungan personal factors dengan unsafe actions pada pekerja pengelasan di PT Dok dan Perkapalan Surabaya. Jurnal Manajemen Kesehatan Yayasan RS. Dr. Soetomo, 3(2), 214-224.

Zhang, S., \& Wang, J. (2015). Analysis of South Korea Sewol sunken ferry accident based on behavioral safety. Journal of Coastal Research, 73(1), 611-613. 